JURNAL SAINTIFIK VOL. 1 NO. 2, JULI 2015

\title{
MENINGKATKAN KEMAMPUAN PEMECAHAN MASALAH DALAM PEMBELAJARAN MATEMATIKA DENGAN PENDEKATAN OPEN ENDED PROBLEM
}

\author{
${ }^{* 1}$ Jeranah, ${ }^{* 2}$ ST. Fatimah \\ 1,2 STKIP-YPUP Makassar \\ e-mail: jeranahku@gmail.com, fatimahsirate@yahoo.com
}

\begin{abstract}
Abstrak
Kualitas hasil belajar matematika siswa kelas XI IPA SMA Negeri 1 Sungguminasa pada tahun ajaran 2012/2013 berada pada kategori sedang, yakni rata-rata kelas yang hanya mencapai skor 58. Salah satu faktor penyebab rendahnya kualitas hasil belajar matematika siswa kelas XI IPA SMA Negeri 1 Sungguminasa ini adalah lemahnya kemampuan pemecahan masalah matematika siswa. Alternatif pemecahan masalah ini adalah penerapan pendekatan open ended problem dalam pembelajaran. Untuk itu dilakukan penelitian tindakan kelas yang bertujuan meningkatkan kemampuan pemecahan masalah dalam pembelajaran matematika dengan pendekatan open ended problem padasiswa kelas XI IPA SMA Negeri 1 Sungguminasa. Penelitian ini dilaksanakan secara bersiklus dengan tahap-tahap perencanaan, pemberian tindakan, observasi dan refleksi. Perangkat pendukung pembelajaran yang direncanakan dikembangkan penelitian ini adalah RPP dan LKS yang berbasis pada pendekatan open ended problem. Instrumen yang digunakan pada penelitian ini adalah lembar observasi aktivitas siswa, lembar observasi keterlaksanaan pembelajaran, tes pemecahan masalah, dan angket respon siswa. Data-data yang akan dianalisis pada penelitian ini adalah aktivitas siswa selama pembelajaran, keterlaksanaan pembelajaran open ended problem, skor pemecahan masalah matematika siswa, dan respon-respon siswa setelah pembelajaran. Data-data pada peelitian ini dianalisis dengan pendekatan kuantitatif deskriptif dan kualitatif.Hasil penelitian menunjukkan secara kuantitaf yaitu skor rata-rata kemampuan pemecahan masalah matematika siswa pada siklus I adalah 58,86 dan skor rata-rata hasil belajar matematika siswa pada siklus II adalah 65,37. Sedangkan dari hasil analisis kualitatif menunjukkan bahwa meningkatnya kreatifitas siswa dalam menyelesaikan masalah lebih dari satu cara. Dari hasil analisis kuantitatif dan kualitatif ini dapat disimpulkan bahwa telah terjadi peningkatan kemampuan pemecahan masalah matematika siswa dari siklus I ke siklus II.
\end{abstract}

Kata kunci: Pemecahan masalah, pendekatan open ended

\section{PENDAHULUAN}

Perbaikan mutu pendidikanterusdigalakkan, baik oleh pemerintah maupun guru sebagai pelaksana pembelajaran di sekolah. Salah satu diantaranya adalah dengan pembenahan kurikulum yang dewasa ini diarahkan pada kurikulum yang berbasis kompetensi sejak tahun 2004 yang kemudian diperbaharuidengan Kurikulum Tingkat Satuan Pendidikan (KTSP)sejaktahun 2006. Pada tahun 2013 ini kembali pemerintah membenahi kurikulum dalam setiap satuan pendidikan. Kurikulum dalam sistem pendidikan nasional dikembangkan agar siswa dapat meningkatkan prestasi belajarnya serta aktif dalam pembelajaran. Namun hingga kini siswa masih cenderung menerima langsung pengetahuan apa yang disampaikan oleh gurunya, padahal pada dasarnya setiap anak memiliki jiwa penyelidik, ingin mengetahui kekeliruan, dan mencari semua fakta dalam menyelesaikan masalah. Peniruan metode orang lain sesungguhnya menjadikan siswa tetap berada di belakang, yang seharusnya dilakukan siswa 
adalah memenangkan kompetisi. Kondisi ini tak terkecuali ditemukan dalam pembelajaran matematika di sekolah.

Pemilihan pendekatan yang dapat digunakan guru haruslah tepat, agar dapat menumbuhkan kompetensi siswa dalam belajar matematika. Masalah-masalah yang pada umumnya timbul pada siswa saat ini adalah sulitnya siswa memecahkan suatu masalah dan cara menyelesaikan masalah tersebut. Hal ini tidak lepas dari apa yang dialami oleh siswa SMA Negeri 1 Sungguminasa khususnya kelas XI IPAdalam proses pembelajaran matematika di sekolah. Pengalaman guru yang mengajarkanmatematika di kela sini menemukan adanya kendala-kendala dalam upaya meningkatkan hasil belajar matematika. Hasil ini ditunjukkan dari hasil ujian matematika pada semester genap2012/2013, yang masih mencapai rata-rata kelas sebesar 58,5 yang tidak jauh berbeda dibandingkan pencapaian rata-rata kelas pada semester ganjil sebelumnya yang mencapai 58,2.

Hasil diskusi penulis dengan guru pengajar mendapatkan hasil analisa bahwa salah satu faktor penting yang cukup berpengaruh adalah tingkat kemampuan pemecahan masalah matematika siswa dalam pembelajaran matematika masih rendah. Secara umum siswa tidak terbiasa menghadapi soal-soal yang tidak rutin dan mereka mudah menyelesaikan soal-soal yang rutin, yaitu soal-soal matematika yang biasanya dicontohkan dan diselesaikan guru di kelas ketika mengajarkan suatu materi matematika. Siswa tidak mampu berpikir secara kreatif dan kurang mampu mengaitkan pengetahuan konseptual yang dibutuhan dalam menyelesaikan suatu masalah matematika.

Kesulitantersebutbanyakdisebabkanolehkurangnyapengetahuan yang cukup dan kurangnya strategi pemecahan masalah yang dimiliki oleh siswa.Kondisi ini berdampak pada tumbuhnya satu masalah yang dihadapi oleh siswa kelas XI IPAyaitu kurang aktifnya siswa dalam proses pembelajaran matematika yang diakibatkan oleh kesulitan siswa memecahkan masalah.Pendekatan pembelajaran merupakan salah satu faktor yang penting dalam meningkatkan kemampuan pemecahan masalah matematika siswa, sehingga diperlukan adanya pendekatan-pendekatan yang baru dalam pelaksanaan proses pembelajaran di sekolah.

Depdiknas (2008:7) menyatakan "Pendekatan (approach) adalah cara umum memandang suatu permasalahan atau objek kajian, sehingga muncul dampak dari cara pandang tersebut." Ketepatan dalam memilih suatu pendekatan akan menjadi pedoman atau orientasi dalam pemilihan komponen kegiatan pembelajaran lainnya terutama strategi dan metode pembelajaran.

Untukitupendekatandalamkegiatanpembelajaranberfungsisebagaiacuanpengorganisasianbahan ajar yang akandipelajariolehsiswaselama proses pembelajaran.

Pendekatan pembelajaran yang digunakan dalam penelitian ini adalah pembelajaran dengan pendekatan open-ended.Pendekatan open ended problem dalam pembelajaran matematika memberikan kesempatan kepada siswa untuk memperoleh pengetahuan atau pengalaman menemukan, mengenali, dan memecahkan masalah dengan beberapa teknikataucarapenyelesaian.

Kemampuan untuk memecahkan masalah juga salah satu factor yang dapat mempengaruhi hasil belajar siswa rendah. Oleh karena itu, perbaikan dan peningkatan mutu pembelajaran matematika jadi hal yang penting agar mampu mengikuti perkembangan yang ada. Pembelajaran matematika dalam Standar Isi Kurikulum Tingkat Satuan Pendidikan bertujuan salah satunyayaitu kemampuan memecahkan masalah yang meliputikemampuan memahamimasalah,merancang model matematika,menyelesaikanmodeldanmenafsirkansolusi yang diperoleh (Depdiknas, 2006:417).

Oleh karena itu permasalahan rendahnya kemampuan pemecahanma salah matematikasiswa SMA Negeri 1 Sungguminasa penting diselesaikan dan ditingkatkan kualitasnya dengan menggunakan pendekatan open ended problem. 
JURNAL SAINTIFIK VOL. 1 NO. 2, JULI 2015

\section{METODE PENELITIAN}

Jenis Penelitian adalah Penelitian Tindakan Kelas (PTK). MenurutA rikunto (2009:3) "Penelitian tindakan kelas merupakan suatu pencermatan terhadap kegiatan belajar berupa sebuah tindakan, yang sengajadimunculkan dan terjadi dalamsebuah kelas secara bersamaan." SedangkanSuhardjono (2008:58) menyatakan bahwa "PTK adalah penelitian tindakan yang dilakukan di kelas dengan tujuan memperbaiki atau meningkatkan mutu praktik pembelajaran." Jadi Penelitian tindakan adalah satu strategi pemecahan masalah yang memanfaatkan tindakan nyata dalam bentuk proses pengembangan inovatif yang dicoba sambil jalan dalam mendeteksi dan memecahkan masalah. Sesuai dengan jenis penelitian yang dipilih, yaitu penelitian tindakan, maka penelitian ini menggunakan model penelitian tindakan dari Kemmisdan Taggart dalam Suhardjono (2008:73) "Yaitu berbentuk kegiatan berulang dari siklus yang satu ke siklus yang berikutnya.Setiap siklus meliputi planning (perencanaan), action (tindakan), observation (pengamatan), dan reflection (refleksi).Langkah pada siklus berikutnya adalah perencanaan yang sudah direvisi, tindakan, pengamatan, dan refleksi”.

Penelitian ini dilaksanakan di SMA Negeri 1 Sungguminasa dan subjek penelitian adalah siswa kelas XI IPA SMA Negeri 1 Sungguminasa.

Sumber data penelitian adalah personil penelitian yang terdiri dari guru dan siswa. jenis data yang diperoleh adalah data kuantitatif dan data kualitatif yang terdiri dari data hasil tes kemampuan pemecahan masalah matematika siswa, data hasil observasi selama proses belajar mengajar, dan data tanggapan siswa terhadap pendekatan open ended problem.Cara pengambilan data:

a. Lembar observasi, untuk mengamati proses belajar mengajar selama tindakan diberikan.

b. Tes kemampuan pemecahan masalah matematika, untuk mengumpulkan data kemampuan pemecahan masalah siswa.

c. Angket respon siswa, untuk mengetahui tanggapan siswa terhadap apa yang dialami selama pelaksanaan tindakan pembelajaran dengan pendekatan open ended problem.

\section{HASIL DAN PEMBAHASAN}

Analisis secara kuantitatif kemampuan pemecahan masalah matematika siswaberdasarkanhasiltessiklus I dapatdilihatdalamtabel di bawahini :

Tabel 1. Statistik Skor Kemampuan Pemecahan Masalah Matematika Siswa pada Siklus I

\begin{tabular}{lc}
\hline \multicolumn{1}{c}{ Statistik } & NilaiStatistik \\
\hline Jumlahresponden & 35 \\
Mean & 58.8571 \\
Median & 61.0000 \\
Modus & 61.00 \\
StandarDeviasi & 12.95727 \\
Varians & 167.89076 \\
Skewness & -0.384 \\
Kurtosis & -0.326 \\
Rentang & 52.00 \\
Minimun & 30.00 \\
Maksimun & 82.00 \\
\hline
\end{tabular}

Dari tabel di atas menunjukkan bahwa skor rata-rata perolehan untuk tes pada siklus I adalah 58,86 dari skor ideal (total) yang dicapai yaitu 100 sedangkan skor terendah yang mungkin dicapai adalah 0. Perolehan skor untuk tes siklus I yaitu 82,00 untuk skor yang tertinggi dan 30,00 yang merupakan skor terendah. 
Nilai median atau nilai tengah dari data yang diperoleh sebesar 61,00, modus yaitu nilai yang paling banyak frekuensinya diperoleh siswa sebesar 61 simpangan baku yaitu nilai penyimpangan titik-titik data secara umum dari nilai rata-ratanya sebesar 12,96 dan selanjutnya nilai variansi yaitu ragam atau penyebaran data yang diperoleh sebesar 167,891.

Nilai skewness yaitu koefisien kemiringan kurva sebesar $-0,384$ yang berarti kurva condong atau miring kekiri (arah negatif) sehingga memberikan arti bahwa pada umumnya kemampuanpemecahanmasalahmatematika siswa berada di atas atau di sekitar nilai rataratanya. Nilai kurtosis yaitu kecembungan kurva sebesar -0,326 yang berarti model kurva agak datar disebut platikurtik.

Tabel 2. Distribusi Frekuensi Skor Kemampuan Pemecahan Masalah Matematika Siswa pada

\begin{tabular}{clcc}
\multicolumn{4}{c}{ Siklus I } \\
\hline Nilai & \multicolumn{1}{c}{ Kategori } & Frekuensi & Persentase \\
\hline $0-34$ & SangatRendah & 2 & $5.72 \%$ \\
$35-54$ & Rendah & 9 & $25.71 \%$ \\
$55-64$ & Sedang & 13 & $37.14 \%$ \\
$65-84$ & Tinggi & 11 & $31.43 \%$ \\
$85-100$ & SangatTinggi & 0 & $0 \%$ \\
& & & $\mathbf{1 0 0} \%$ \\
\hline
\end{tabular}

Dari Tabel 4.1 dan Tabel 4.2 di atas menunjukkan bahwa pada Siklus I terdapat 2 siswa $(5,72 \%)$ dalam kategori sangat rendah kemampuan pemecahan masalah matematikanya, 9 siswa $(25,71 \%)$ dalam kategori rendah, 13 siswa $(37,14 \%)$ siswa dalam kategori sedang, 11 siswa $(31,43 \%)$ dalam kategori tinggi dan tidak ada siswa dalam kategori sangat tinggi, sedangkan skor rata-rata kemampuan pemecahan masalah matematika siswa pada tabel 4.1 berada dalam kategori sedang. Hal ini berarti bahwa tingkat kemampuan pemecahan masalah matematika siswa pada Siklus I termasuk sedang.

Tabel 3. Statistik Skor Kemampuan Pemecahan Masalah Matematika Siswa pada Siklus II

\begin{tabular}{lc}
\hline \multicolumn{1}{c}{ Statistik } & NilaiStatistik \\
\hline Jumlahresponden & 35 \\
Mean & 65.37 \\
Median & 67.0000 \\
Modus & 71.00 \\
StandarDeviasi & 9.45605 \\
Varians & 89.41681 \\
Skewness & -0.422 \\
Kurtosis & -0.188 \\
Rentang & 40.00 \\
Minimun & 45.00 \\
Maksimun & 85.00 \\
\hline
\end{tabular}

Dari tabel di atasmenunjukkanbahwaskor rata-rata perolehansiswaadalah 65,37 dariskor ideal (total) yang dicapaiyaitu 100 sedangkanskorterendah yang mungkindicapaiadalah nol. Perolehanskoryaitu 85,00 untukskor yang tertinggidan 45,00 yang merupakanskorterendah.

Nilai median atau nilai tengah dari data yang diperoleh sebesar 67,00; modus yaitu nilai yang paling banyak frekuensinya diperoleh siswa sebesar 71; simpangan baku yaitu nilai penyimpangan titik-titik data secara umum dari nilai rata-ratanya sebesar 9,46; dan selanjutnya nilai variansi yaitu ragam atau penyebaran data yang diperoleh sebesar 89,42.

Nilai skewness yaitu koefisien kemiringan kurva sebesar -0,422 yang berarti kurva condong atau miring kekiri (arah negatif) sehingga memberikan arti bahwa pada umumnya 
JURNAL SAINTIFIK VOL. 1 NO. 2, JULI 2015

kemampuanpemecahanmasalahmatematika siswa berada di atas atau di sekitar nilai rataratanya. Nilai kurtosis yaitu kecembungan kurva sebesar $-0,188$ yang berarti model kurva agak datar disebut platikurtik.

Apabila kemampuanpemecahanmasalahmatematika siswa di atas dikelompokkan ke dalam 5 kategori maka diperoleh distribusi dan skor tersebut dan persentase seperti pada tabel berikut ini:

Tabel 4. Distribusi Frekuensi Skor KemampuanPemecahanMasalahMatematikaSiswa pada

\begin{tabular}{clcc}
\multicolumn{5}{c}{ Siklus II } \\
\hline Nilai & \multicolumn{1}{c}{ Kategori } & Frekuensi & Persentase \\
\hline $0-34$ & SangatRendah & 0 & $0 \%$ \\
$35-54$ & Rendah & 6 & $17.14 \%$ \\
$55-64$ & Sedang & 10 & $28.57 \%$ \\
$65-84$ & Tinggi & 18 & $51.43 \%$ \\
$85-100$ & SangatTinggi & 1 & $2.85 \%$ \\
& & & \\
\hline & \multirow{2}{*}{ Jumlah } & $\mathbf{3 5}$ & $\mathbf{1 0 0} \%$ \\
\hline
\end{tabular}

Pada tabel di atas menunjukkan bahwa tidak ada siswa dalam kategori sangat rendah kemampuan pemecahan masalah matematikanya, dalam kategori rendah 6 siswa $(17,14 \%)$, kategori sedang 10 siswa $(28,57 \%)$, kategori tinggi 18 siswa $(51,43 \%)$ dan seorang siswa dalam kategori sangat tinggi $(2,85 \%)$ sedangkan skor rata-rata kemampuan pemecahan masalah matematika pada tabel 4.3 berada dalam kategori tinggi.

Selain terjadi peningkatan kemampuanpemecahanmasalahmatematikadari siklus I ke siklus II, terjadi pula sejumlah perubahan sikap siswa dalam proses pembelajaran. Perubahan tersebut merupakan data kualitatif yang diperoleh dari lembar observasi pada setiap pertemuan selama siklus I dan siklus II.

Berdasarkan indikator ketuntasan belajar yang diberlakukan di SMA Negeri 1 Sungguminasa dalam mata pelajaran matematika maka diperoleh bahwa pada siklus I siswa yang tergolong kategori tuntas belajar sebanyak 21 orang dan pada siklus II yang tergolong kategori tuntas belajar sebanyak 28 orang dan pada siklus I siswa kelas XI IPA 3 tidak tuntas secara klasikal, sedangkan pada siklus II siswa kelas XI IPA I $_{3}$ tuntas secara klasikal.

Meskipun telah terjadi peningkatan kemampuan pemecahan masalah matematika siswa tetapi tidak sedikit kendala yang dihadapi dalam penelitian. Adapun kendala-kendala tersebut adalah:

1. Siswa tidak dapat berkonsentrasi penuh dan berkreasi dalam mencari berbagai kemungkinan cara dalam menyelesaikan soal-soal yang diberikan karena terbatasnya waktu yang disediakan.

2. Menanamkan konsep penyelesaian soal dengan menggunakan lebih dari satu cara kepada siswa sangat sukar sebab mereka terbiasa mengerjakan soal dengan menggunakan satu cara.

Selain kendala-kendala di atas, kendala lain yang dihadapi adalah kendala yang berhubungan dengan kelemahan pendekatan open ended problem itu sendiri. Seperti yang telah dikemukakan pada Bab II bahwa kelemahan dari pendekatan open ended problem, diantaranya adalah:

- Membuat dan menyiapkan masalah matematika yang bermakna bagi siswa bukanlah pekerjaan mudah.

- Mengemukakan masalah yang langsung dapat dipahami siswa sangat sulit sehingga siswa yang mengalami kesulitan bagaimana merespon permasalahan yang diberikan.

- Mungkin ada sebagian siswa yang merasa bahwa kegiatan belajar mereka tidak menyenangkan karena kesulitan yang mereka hadapi.

Adapun langkah-langkah yang dilakukan untuk mengatasi kelemahan-kelemahan pendekatan open ended problem diatas adalah sebagai berikut: 
1. Guru sebaiknya lebih banyak menjelaskan maksud dari masalah-masalah yang diberikan sehingga siswa mudah menyelesaikan masalah tersebut.

2. Guru sebaiknya lebih banyak memberikan masalah-masalah open ended kepada siswa yang serupa dengan masalah sebelumnya sesuai dengan indikator yang ingin dicapai setiap sub pokok bahasan.

3. Mengidentifikasi kesulitan-kesulitan yang mungkin dialami siswa pada saat menyelesaikan soal pada proses pembelajaran berlangsung kemudian memberikan bimbingan sehubungan dengan kesulitan tersebut.

\section{KESIMPULAN}

1. Dari lembar observasi dan tanggapan yang dianalisis secara kualitatif jumlah siswa mengalami perubahan sikap ke arah yang positif untuk setiap indikator yang diamati pada siklus I ke siklus II.

2. Pada siklus I, pada umumnya siswa belum mampu menyelesaikan masalah lebih dari satu cara. Berdasarkan hasil refleksi pada siklus I kemudian ditindaklanjuti pada siklus II dengan mengadakan perbaikan terhadap kekurangan-kekurangan pada siklus I yaitu guru lebih banyak memberikan masalah-masalah open ended kepada siswa yang serupa dengan masalah sebelumnya sesuai dengan indikator yang ingin dicapai setiap sub pokok bahasan.

3. Penerapan pendekatan open ended problem dalam pembelajaran matematika dapat meningkatkan kemampuan pemecahan masalah matematika siswa kelas XI IPA ${ }_{3}$ SMA Negeri 1Sungguminasa. Hal ini dapat dilihat dari peningkatan skor rata-rata tes kemampuan pemecahan masalah matematika siswa yang pada siklus I sebesar 58,86 dan pada siklus II menjadi 65,37 .

\section{DAFTAR PUSTAKA}

Arikunto. 2009. Dasar-Dasar Evaluasi Pendidikan .Jakarta :BumiAksara

Depdiknas. 2006. Peraturan Mentri Pendidikan Nasional Republik Indonesia nomor 22 Tahun 2006 Tentang Standar Isi Untuk Satuan Pendidikan Dasar dan Menengah. Jakarta: Depdiknas

Depdiknas. 2008. Pengembangan dan Penerapan Model Pembelajaran Berbasis Kompetensi. Jakarta :Depdiknas Gelar Dwirahayu

Dwirahayu. 2007.Pendekatan Barudalam Proses Pembelajaran Matematika dan Sains Dasar. Sebuah Antologi. Jakarta: IAIN Indonesian

Suhardjono. 2008. Penelitian Tindakan Kelas. Jakarta :Rajawali

Suherman, H, dkk. 2003. Strategi Pembelajaran Matematika Kontemporer. Universitas Pendidikan Indonesia: JICA.

Suyatno. 2009. Menjelajah Pembelajaran Inovatif. Surabaya: Mas Media BuanaPustaka.

Upu, Hamzah. 2003. Problem Posing dan Problem Solving Dalam Pembelajaran Matematika. Bandung: PustakaRamadhan. 